\title{
Social Media and Improved Learning Achievement in Junior High Students of Coastal Pangkep
}

\author{
Muhammad Farid ${ }^{1}$, Andi Alimuddin Unde ${ }^{2}$ \\ \{faridemsil@yahoo.com ${ }^{1}$, undealimuddin@yahoo.co.id ${ }^{2}$ \} \\ Department of Communication Science, Hasanuddin University, Jl. Perintis Kemerdekaan KM.10, \\ Makassar, Indonesia
}

\begin{abstract}
Research on the Analysis of the Relationship between the Use of Social Media and Improving Student Learning Achievement in the Pangkep Regency Coastal Region, with the aim to determine the frequency and duration of social media use for students related to learning. And to analyze the relationship between the use of social media and the improvement of students' learning achievements in the Coastal Region Middle School. By using a quantitative approach that is distributing questionnaires to second and third grade junior high school students. The data expected from this questionnaire is, the use of social media both in terms of frequency of use and duration of use. As for other data collected through the report cards of each respondent, to analyze whether there is an increase in learning achievement is associated with a tendency to use social media related to school learning, especially in coastal areas which incidentally the quality of education is still low. The results showed that all respondents had the opportunity to open social media with different frequencies in searching and searching for information related to learning in school. The frequency in question is; one to two times a week, three to four times a week, five to six times a week and more than six times a week. While the duration of searching for learning information also shows numbers ranging from; one to fourteen minutes, fifteen to thirty minutes, thirty-one to forty-four minutes and more than forty-four minutes.
\end{abstract}

Keywords: New media, Social media, Learning with technology, Education technology

\section{Introduction}

The launch of the book of Second Media Age by Poster is considered as a marker of the start of a new period in which interactive technology and network communication, especially cyberspace will change society [1]. 
New Media is a new development of media that has been used by humans. Its character which is a digital form certainly makes it easy to exchange information and various other activities. But in its development, New Media can provide negative values as well, namely being able to access sites that smell pornographic and violent easily and have an addictive effect for its users. So, the development of New Media should also be followed by the policies of those who use it.

One of the problems of education in Indonesia is that the teaching and learning process given in class generally only expresses concepts in a direction. Teaching and learning process that is mostly done is a lecture learning model by means of one-way communication (teaching centered), of which $90 \%$ are active instructors. Whereas students usually only function their sense of sight and sense of hearing. An introduction to this concept does not mean that it is not needed, but what usually happens only to the extent of understanding the concept, without continuing on the application.

The learning model as mentioned above is considered not to explore the insights of students' knowledge, attitudes and behavior of children/students. Because during the teaching and learning process, if the concentration of the child is less than optimal, then the child will have difficulty receiving the material taught at the time, so it is also difficult for the child to store the subject matter in the child's memory/memory/impression.

Child-centered learning is learning using a pair of perspectives, namely focus on individual learners (descent, experience, perspective, background, talents, interests, capacities, and needs) with a focus on learners, the best knowledge about learning and how it arises as well as about the most effective teaching practices in increasing the level of motivation, learning, and achievement for learners.

This dual focus then provides information and encourages educational decision making. Through the learning process with the active involvement of children this means the teacher does not take the child's right to learn in the real sense. In the learning process that is centered on children outside of school (informal), then the child children get the opportunity and facilitation to build their own knowledge so that they will gain a deep understanding (depth learning), and on

As is known, there are many teenagers who are smart and adept at accessing the internet. Even many underage children have social media accounts like Facebook, Twitter, Instagram, Path, Tumblr etc. As well as being driven by the number of companies that issue various brands of Smartphones, Tabs and various other products ranging from low to high prices. As well as the features provided by the internet package that is cheap and can provide comfort and freedom for its users. In addition, if the percentage that uses is adolescents among the junior high school class 1 to junior high school class 2, it is higher or more registered.

Education is the property of everyone, including netizens who want to gain knowledge even though it is not through formal channels. In order for the purpose of education to educate the life of humanity, educational activists will certainly endeavor to be able to provide learning wherever, whenever and whatever the conditions. Internet education media is one of the developments of the Internet that is made in the field of education, many social media users in the world make teachers follow the tendency to provide their knowledge through social media. For many educational institutions in the world, for example, these institutions began to open themselves to the community through social media. For example, Ohio State University in 2007 opened several social media accounts including Facebook, Flickr, and YouTube Channel. The University intentionally opened a social media account to make it easier for the campus to introduce its University to the general public. In addition, the use of social media also facilitates them in giving public lectures to the public. 
The problem now is that small objects are often used for the sake of accessing things that are entertainment, and information that is not very useful for daily life. This includes students who use this device a lot and play on social media which is assumed that things that are accessed or listened to are not directly related to their education or their learning in school. The purpose of the study was to determine the frequency and duration of use of social media for students related to learning.

\section{Research Method}

This type of research is a survey research method through descriptive comparative studies that is research that presents a description of existing phenomena by comparing the same variables for different samples [2]. This study analyzes the relationship between the use of social media and improving student learning achievement in the Pangkep Regency Coastal Region. What will be done to students of Satap Liukang Tupabbiring State Junior High School 3, Satap Liukang Tupabbiring State Junior High School 12 and Satap Liukang Tupabbiring State Junior High School 7 with the aim of capturing data through question instruments so that quantitative measurements can be made.

According to Sugiyono [3], population is a generalization area consisting of objects or subjects that have certain quantities and characteristics that are applied by researchers to be studied and then drawn conclusions. In this study the population was all students, Satap Liukang Tupabbiring State Junior High School 3, Satap Liukang Tupabbiring State Junior High School 12 and Satap Liukang Tupabbiring State Junior High School 7.

The sample selection in this study uses purposive sampling technique, which is a technique used if the sample members are selected specifically based on the research objectives [4]. The sample of this study was Class VIII and IX students under the age of under 1516 years. Because of the different research locations so that they can be compared with other locations. Therefore, the sample is expected to be the same. This research uses primary data and secondary data. Primary data is data obtained from respondents by making closed questions in a questionnaire then the questionnaire is distributed to respondents, and interviewing respondents who are guided by the questionnaire.

This data employs univariate data analysis was performed to obtain an overview of each variable, the frequency distribution of the various variables studied both the dependent variable and the independent variable. This analysis can be presented in tabular form and then described the results of the data. By looking at the frequency distribution it can be seen the description of each variable in the study.

Bivariate analysis is carried out to find out about the differences between the two groups can be used with independent sample $t$ test. The process of testing the independent sample $t$ test is comparing the averages of two groups that are not related to each other, whether significantly the two groups have the same average or not [2]. 


\section{Results and Discussion}

\subsection{Research Results}

Frequency and duration use of social media for learning by students. The initial survey in this assessment respondents numbered 58 people located in junior high schools located on the coast of the district of Segeri Mandalle. The rest will be carried out when students begin school.

Table 1. Media facilities at home; all respondents had a TV and radio. TVs were usually turned on during the evening and radio was the preferred form of media during the day.

\begin{tabular}{lcc}
\hline Facility & Frequency & $\%$ \\
\hline TV & 58 & 100 \\
Radio & 58 & 100 \\
Broadband Internet & - & - \\
Newspapers & - & - \\
Magazines & - & - \\
\hline
\end{tabular}

Table 2. Smartphone ownership; many students owned personal smartphones and these were typically the children of households with above-average incomes or pond farmers. Many did not have personal phones but were allowed to borrow their parent's phone for certain needs.

\begin{tabular}{ccc}
\hline Variables & Frequency & $\%$ \\
\hline Yes/own smartphone & 32 & 55 \\
No/parent's phone & 26 & 45 \\
Total & 58 & 100 \\
\hline
\end{tabular}

Table 3. How long have you owned a smartphone? Most respondents owned a smartphone for 1-2 years and parents of students typically owned phones for more than 2 years.

\begin{tabular}{ccc}
\hline Variable & Frequency & $\%$ \\
\hline$<1$ year & 3 & 5 \\
1 - 2 years & 29 & 50 \\
$>2$ years & 26 & 45 \\
Total & 58 & 100 \\
\hline
\end{tabular}

Table 4. Use of smartphone for seeking information relating to studies; all respondents used smartphones to search for information related to their school studies whether it was a personal phone or a parent's phone.

\begin{tabular}{ccc}
\hline Variable & Frequency & $\%$ \\
\hline Yes & 58 & 100 \\
No & - & - \\
Total & 58 & 100 \\
\hline
\end{tabular}


Table 5. Types of Information Students Searched For; students searched for online information on topics like mathematics, English studies, Indonesian studies, natural sciences, social sciences, sports, and arts. Mathematics, Indonesian language studies, natural sciences, and social sciences were the most often searched topics.

\begin{tabular}{ccc}
\hline Information & Frequency & $\%$ \\
\hline Mathematics & 58 & 100 \\
English Studies & 15 & 26 \\
Indonesian Studies & 58 & 100 \\
Natural Sciences & 58 & 100 \\
IPS & 58 & 100 \\
Sports & 21 & 36 \\
Art & 30 & 52 \\
\hline
\end{tabular}

Table 6. Applications Used; students most often used Instagram and WhatsApp to find educational information, though Facebook and Twitter were also quite popular.

\begin{tabular}{ccc}
\hline Application & Frequency & $\%$ \\
\hline Instagram & 58 & 100 \\
WhatsApp & 58 & 100 \\
Facebook & 25 & 43 \\
Twitter & 27 & 47 \\
\hline
\end{tabular}

Table 7. Social media is helpful to me for finding the information I seek

\begin{tabular}{|c|c|c|c|}
\hline Variables & & Frequency & $\%$ \\
\hline Very helpful & & 42 & 72 \\
\hline Helpful & & 16 & 38 \\
\hline Slightly helpful & & - & - \\
\hline Not helpful & & - & - \\
\hline & Total & 58 & 100 \\
\hline
\end{tabular}

Table 8. How frequently do you search for information relating to school studies?

\begin{tabular}{ccc}
\hline Variables & Frequency & $\%$ \\
\hline $1-2$ times per week & 10 & 17 \\
$3-4$ times per week & 25 & 43 \\
$5-6$ times per week & 14 & 24 \\
$>6$ times per week & 9 & 16 \\
Total & 58 & 100 \\
\hline
\end{tabular}

Table 9. Do you feel the time you spend searching for educational materials is sufficient? According to respondents, the time spent looking for school-related materials was either very sufficient $(60 \%$ of respondents) or sufficient ( $40 \%$ of respondents)

\begin{tabular}{ccc}
\hline Variables & Frequency & $\%$ \\
\hline Very sufficient & 35 & 60 \\
\hline
\end{tabular}




\begin{tabular}{lccc}
\hline Sufficient & 25 & 40 \\
Barely sufficient & & - & - \\
Not sufficient & & - & - \\
& Total & 58 & 100 \\
\hline
\end{tabular}

Table 10. How much time do you spend searching for information relating to your school studies? Most students spent an average of 15 minutes (55\% of respondents) with only 2 students ( $4 \%$ ) claiming to spend more than 30 minutes.

\begin{tabular}{ccc}
\hline Variables & Frequency & $\%$ \\
\hline $1-15$ minutes & 32 & 55 \\
$16-30$ minutes & 24 & 41 \\
$>30$ minutes & 2 & 4 \\
Total & 58 & 100 \\
\hline
\end{tabular}

\subsection{Discussion}

Social media is a product of modern information and communication technology that is currently growing rapidly and has become a part of Indonesian people's lives. As an internetbased platform, social media provides a space for unlimited interaction that is not bound by time or physical territory. This allows interaction in social media takes place broadly and continuously so as to create a digital community that continues to live and thrive.

Social media is an online media, with its users can easily participate, share and create content including blogs, social networks, forums and the virtual world. In the world of social media education also plays an important role in improving the quality of students. Kaplan and Haenlein [5] define social media as "an internet-based application group that builds on the ideology and Web 2.0 technology that enables the creation and exchange of user generated content".

In the world of social media education also plays an important role in improving the quality of students. The social media that is mostly used by teenagers is Instagram. Instagram itself in the beginning of 2016 has increased the number of users to more than 400 million users with around 80 million images uploaded every day. Indonesia has around 12,000 users who are members of the Instagram user community called Instameet [6].

From the research it turns out that social media can be used for the sake of finding learning information related to subjects in school. Lack of available reading material makes students have to find information related to their own learning. In order to catch up when compared to other students who are in town.

Based on the actual data students have a lot of time to use their smartphone to search for and find lesson information, but their free time is also used to help parents, work in the fields or ponds and there are also students going to sea with their parents. So, they think the frequency of using a smartphone is enough.

The duration of time spent searching and searching for related subjects is considered to be inadequate because they only use less than one hour to obtain learning information. Though to trace a lesson takes a lot of time.

Facebook and Twitter are social networks that are widely used by students, the friendship system and the exchange of information that is very easy to do on this site is what causes many students who have an account. 
By utilizing all the conveniences and benefits of Facebook learning activities can also be created, in other words making Facebook a learning medium. Example with the existence of Group facilities on Facebook, we can create a certain community in accordance with our interests and talents. Usually the Group is created based on a field of study program such as " Lovers of Natural Sciences. " In this Group students can easily and freely discuss without being limited by space and time so that discussion here is more interesting and efficient. Finally, students can do an independent learning process without having to be accompanied by a teacher. However, it is even better if the teacher participates in managing the group.

If we read the news or some literature, indeed social media has the potential to reduce learning achievement. 'Explosion' of information, it turns out it can actually lead to increased apathy of the digital generation, especially in the context of learning achievement. The use of social media without control, will cause learners to forget their main tasks at school or college, and choose to enter the virtual world without limits.

\section{Conclusion}

From the results of the study it can be concluded that the frequency of using social media to find and trace learning information at school, is still low. Not routinely every day, but still limited to a certain time only, depending on the conditions and desires of respondents.

The intensity of the time used every time you open social media is also still very minimal, less than it should be used to browse through one lesson material. Their free time is widely used to play and help parents work, in the fields, ponds and join in sailing.

Their free time is widely used to play and help parents work, in the fields, ponds and join in sailing. Social media may improve or reduce their scholastic performance depending on how they utilize it.

For the digital generation, the theory of 'six degrees of separation' which underlies the development of social media, is their bridge to collect as much information and from anyone.

\section{References}

[1] Littlejohn S. W., K. A. Foss.: Teori Komunikasi. Edition 9, Jakarta: Salemba Humanika (2014)

[2] Silalahi U.:Metode Penelitian Sosial, Bandung PT. Refika Aditama (2009)

[3] Sugiyono.:Metode Penelitian Kuantitatif, Kualitatif dan R\&D (Bandung: Alfabeta) (2009)

[4] Usman R.:Aspek-Aspek Hukum Perseorangan dan Kekeluargaan di Indonesia, Jakarta: Sinar Grafika (2006)

[5] Kaplan a M. A. M. dan Haenlein.:Users of the world, unite! The challenges and opportunities of Social Media. Business Horizons.pp. 59-68 (2010)

[6] Pratiwi E. D.:Faktor yang mempengaruhi Niat Menggunakan Instagram dengan the Theory of Reason Ection Menggunakan Amos 21.Jurnal Teknik Komputer. pp. 68-77 (2016) 